Nova Southeastern University

Florida

NSUWorks

NOVA SOUTHEASTERN

UNIVERSITY

8-1-1999

\title{
Effects of Plasma HIV RNA, CD4+ T Lymphocytes, and the Chemokine Receptors CCR5 and CCR2b on HIV Disease Progression in Hemophiliacs
}

\author{
Eric S. Daar \\ Cedars-Sinai Burns \& Allen Research Institute; University of California - Los Angeles \\ Sharyne Donfield \\ Rho, Inc. \\ Edward Gomperts \\ Children's Hospital of Los Angeles \\ Margaret Hilgartner \\ New York Presbyterian Hospital - Cornell Medical Center \\ Keith Hoots \\ University of Texas Health Science Center at Houston \\ Follow this and additional works at: https://nsuworks.nova.edu/cnso_bio_facarticles \\ 2 next page for additional authors \\ Part of the Genetics and Genomics Commons, Immunology and Infectious Disease Commons, and \\ the Medicine and Health Sciences Commons
}

\section{NSUWorks Citation}

Daar, Eric S.; Sharyne Donfield; Edward Gomperts; Margaret Hilgartner; Keith Hoots; David Chernoff; Cheryl Winkler; Stephen J. O'Brien; and Hemophilia Growth and Development Study. 1999. "Effects of Plasma HIV RNA, CD4+ T Lymphocytes, and the Chemokine Receptors CCR5 and CCR2b on HIV Disease Progression in Hemophiliacs." Journal of Acquired Immune Deficiency Syndromes 21, (4): 317-325. https://nsuworks.nova.edu/cnso_bio_facarticles/665

This Article is brought to you for free and open access by the Department of Biological Sciences at NSUWorks. It has been accepted for inclusion in Biology Faculty Articles by an authorized administrator of NSUWorks. For more information, please contact nsuworks@nova.edu. 


\section{Authors}

Eric S. Daar, Sharyne Donfield, Edward Gomperts, Margaret Hilgartner, Keith Hoots, David Chernoff, Cheryl Winkler, Stephen J. O'Brien, and Hemophilia Growth and Development Study 


\title{
Effects of Plasma HIV RNA, CD4 ${ }^{+}$T Lymphocytes, and the Chemokine Receptors CCR5 and CCR2b on HIV Disease Progression in Hemophiliacs
}

\author{
*Eric S. Daar, $†$ Henry Lynn, $\uparrow$ Sharyne Donfield, $\ddagger$ Edward Gomperts, §Margaret W. Hilgartner, \\ "Keith Hoots, 9[David Chernoff, \#Cheryl Winkler, **Stephen J. O’Brien, and the Hemophilia \\ Growth and Development Study \\ *Cedars-Sinai Burns \& Allen Research Institute, Division of Infectious Diseases, Department of Medicine, and the University of \\ California Los Angeles School of Medicine, Los Angeles, California; $†$ Rho, Inc., Chapel Hill, North Carolina; $\neq$ Childrens \\ Hospital Los Angeles, Los Angeles, California; \$New York Hospital-Cornell Medical Center, Division of Pediatric Hematology \\ and Oncology, New York, New York; "University of Texas Medical School at Houston, Departments of Pediatrics and Internal \\ Medicine, Houston, Texas; IIChiron Corp., Emeryville, California; \#Science Applications International Corp. and Intramural \\ Research Support Program, SAIC Frederick, National Cancer Institute_Frederick Cancer Research and Development Center, \\ Frederick, Maryland; and **Laboratory of Genomic Diversity, National Cancer Institute, Frederick, Maryland, U.S.A.
}

\begin{abstract}
Summary: We have investigated the effects of plasma HIV RNA, CD4 ${ }^{+}$T lymphocytes and chemokine receptors CCR5 and CCR2b on HIV disease progression in hemophiliacs. We prospectively observed during follow-up $207 \mathrm{HIV}$-infected hemophiliacs in the Hemophilia Growth and Development Study. Plasma HIV RNA was measured on cryopreserved plasma from enrollment using the Chiron Corporation bDNA (version 2.0) assay. Genoytpe variants $C C R 2 b-64 I$ and $C C R 5-\Delta 32$ were detected using standard molecular techniques. Those with the mutant allele for $C C R 2 b$, and to a lesser extent CCR5, had lower plasma HIV RNA, and higher $\mathrm{CD}^{+}{ }^{+} \mathrm{T}$ lymphocytes than did those without these genetic variants. After controlling for the effects of plasma HIV RNA and $\mathrm{CD}^{+}{ }^{+} \mathrm{T}$ lymphocytes, those with the CCR $2 b$ mutant allele compared with those wild-type, had a trend toward a lower risk of progression to AIDS, adjusted relative hazard of 1.94 (95\% confidence interval [CI], 0.9-4.18; $p=.092)$, and AIDS-related death, relative hazard $1.97(95 \% \mathrm{CI}, 0.98-4.00 ; p=$ .059). We conclude that plasma HIV RNA, CD4 ${ }^{+} \mathrm{T}$ lymphocytes, and $C C R$ genotypes are correlated, and the protective affect of $C C R 2 b$ against HIV disease progression is not completely explained by plasma HIV RNA or CD4 ${ }^{+}$T-lymphocyte number. Key Words: Genetic resistance-Host factors-Markers-Viral load-Chemokine receptors.
\end{abstract}

The rate of disease progression in HIV-1-infected individuals is heterogeneous. Several virologic and host factors have been shown to influence the rate of disease progression from the time of infection to AIDS and

Address correspondence and reprint requests to Eric S. Daar, CedarsSinai Medical Center, Division of Infectious Diseases, B217, 8700 Beverly Boulevard, Los Angeles, CA 90048, U.S.A.; email: Daar@ CSHS.org.

The content of this publication does not necessarily reflect the views or policies of the Department of Health and Human Services, nor does mention of trade names, commercial products, or organizations imply endorsement by the U.S. Government.

Manuscript received October 7, 1998; accepted March 3, 1999. death. Virologic factors include biologic phenotype, in particular the ability to induce syncytium in vitro (1-3) and plasma HIV RNA concentration. Longitudinal studies have demonstrated the relationship between ongoing viral replication and the pathogenesis of HIV disease (4-6), with a single plasma HIV RNA measurement being a potent predictor of disease progression in various different cohorts (7-12). In addition, host factors have received increasing attention for their role in determining clinical outcomes. Younger age at the time of HIV infection and select HLA profiles have been associated with delayed disease progression (13-15). More re- 
cently, the identification of genotypic variants for select chemokine receptors, namely $C C R 5$ and $C C R 2 b$, has been shown to be protective against progression to AIDS and death. In several studies, the 32 amino acid deletion in CCR5, CCR5- $\triangle 32$, has been associated with improved clinical outcomes (16-21). Similarly, a mutation in the $\mathrm{N}$-terminus of $C C R 2 b, C C R 2 b-64 I$, has been associated with delayed progression to AIDS and death in seroincident (22-25), but not seroprevalent cohorts $(23,26-28)$. The mechanism by which genetic variants for these chemokine receptors delay clinical progression has not been delineated. Our study defines the effect and interaction between these chemokine receptor variants, plasma HIV RNA concentration, and $\mathrm{CD} 4^{+} \mathrm{T}$-lymphocyte number on HIV disease progression in a cohort of infected hemophiliacs.

\section{MATERIALS AND METHODS}

\section{Study Population and Samples Stored}

The Hemophilia Growth and Development Study (HGDS) is a multicenter, U. S. study that enrolled 207 hemophiliacs who acquired HIV infection from exposure to blood products, in most cases between 1982 and 1983. Enrollment occurred in 1989 and 1990 with study subjects ranging in age from 6 to 19 years. Eligibility for enrollment was based on age (date of birth between September 1970 and September 1982), clotting factor usage and fluency in the English language, given that many neuropsychological test instruments were only written in English. A census was taken at participating centers with a total of 2105 children and adolescents identified. Of the 481 eligible study subjects, $69.2 \%$ enrolled. Of those who refused to enroll, most cited the burden of participation as the reason, only $3.5 \%$ did so because of being too ill. The racial and ethnic composition of the group was $73 \%$ white, $15 \%$ Hispanic, $10 \%$ African American, and $2 \%$ other, similar to that of the general U. S. hemophiliac population (29). Loss to vital status followup in this cohort was only $0.48 \%$ during the 7 years of follow-up. Although enrolled subjects necessarily excluded those who progressed to death before enrollment (estimated mean infection period, 7 years), there is little other evidence of bias introduced into the study due to selection or loss to follow-up of cohort participants. Additional details of recruitment and the characteristics of this cohort have been reported previously (30). The human subjects' committees of all collaborating institutions approved the HGDS, and informed consent was obtained from parents or legal guardians, and informed consent or assent was obtained from all participants. Every 6 months, a history was obtained, physical examination performed, and blood was taken for lymphocyte subsets and processed within 24 hours for cryopreservation of plasma and mononuclear cells. Lymphoblastoid cell lines were developed by Epstein-Barr virus transformation as a source of cellular DNA.

For the current investigation, enrollment plasma HIV RNA represents either the study enrollment visit or the first visit for which stored plasma was available for viral quantitation. For the current analysis, participants were categorized as having progressed to AIDS or having an AIDS-related death if they met the 1987 Centers for Disease Control and Prevention (CDC) surveillance definition (31), or died during the first 7 years of follow-up, respectively.

\section{Measurements of Plasma HIV RNA Concentrations}

Heparinized plasma stored at $-70^{\circ} \mathrm{C}$ was used for plasma HIV RNA measurements using a sensitive branched DNA (bDNA) assay (version 2.0, Chiron Corporation, Emeryville, CA, U.S.A.). The assay has a lower quantification limit of $500 \mathrm{copies} / \mathrm{ml}$ and is linear to concentrations as high as $1.6 \times 10^{6}$ copies/ml (one copy of HIV RNA = one molecule of HIV RNA) $(32,33)$. The volume of stored plasma was limited; therefore insufficient specimens were available to perform all assays in duplicate. A pilot study was performed on 26 samples in duplicate to ensure reliability of the replicates, demonstrating that reproducibility was high with a mean coefficient of variation between duplicates of $13.9 \%$, and a correlation coefficient between plasma HIV RNA concentration and $\mathrm{CD}^{+} \mathrm{T}$-lymphocyte number of $-0.42(p=$ 0.03 ). An additional 174 samples were available for testing as singlicates, with quantification performed on a total of 205 of the 207 enrolled subjects.

\section{Genotype Variants}

The CCR5- -32 allele was detected using nested polymerase chain reaction (PCR) methods previously described (16). The CCR2b-64I polymorphism was identified using both single-strand conformation polymorphism/heteroduplex mobility assay and sequence-directed PCR-restriction fragment length polymorphism assays (22).

\section{Study Variables}

We analyzed enrollment plasma HIV RNA concentration, CD4 ${ }^{+} \mathrm{T}-$ lymphocyte numbers, and chemokine receptor genotypes for CCR5 and $C C R 2 b$. Plasma HIV RNA measurements and genotype data were available on 205 and 169 of the 207 seropositive hemophiliacs, respectively. Thirty-eight individuals were missing $C C R 5$ and/or $C C R 2 b$ genotype data with 32 missing both, 3 missing just CCR5, and 3 missing just $C C R 2 b$. To account for the missing data, a logistic discriminant function with baseline age and ethnicity (white versus other) as covariates was used to classify participants into appropriate categories (34). For 27 individuals, plasma HIV RNA were collected after they developed AIDS or at the time of their last known AIDS-free date, and therefore these persons were excluded from the analyses involving time to AIDS. Twelve individuals had not met the 1987 AIDS definition at their time of death $(n=11)$, or died of unknown causes $(n=1)$, and therefore were considered censored at time of death.

Genotype categories included $C C R 5+/+, C C R 5+/ \triangle 32, C C R 2 b+/+$, $C C R 2 b+164 I$ and CCR2b64I/64I. Disease progression was determined as time to development of AIDS according to the 1987 CDC definition (31), and time to AIDS-related death.

\section{Statistical Methods}

The proportion of study subjects who progressed to AIDS or death, stratified by plasma HIV RNA category $(<1000,1000-9999$, and $\geq 10,000$ copies/ml $)$ and $\mathrm{CD}^{+} \mathrm{T}$-lymphocyte category $(<200,200$ $499, \geq 500$ cells $\left./ \mathrm{mm}^{3}\right)$, and chemokine receptor genotype (CCR2b+/+ and $C C R 5+/+$ versus $C C R 2 b+164 I$ or $C C R 5+/ \Delta 32)$ were estimated using the Kaplan-Meier method. Cox proportional hazards regression models were also fitted to assess the independent and joint effects of plasma HIV RNA, CD4 ${ }^{+}$T lymphocytes, CCR $2 b$ and $C C R 5$ genotypes on progression to AIDS or death. Shoenfeld residual plots were used to inspect the assumption of proportional hazards (35). The relationships between chemokine receptor genotype and plasma HIV RNA or $\mathrm{CD} 4^{+}$ 
TABLE 1. The distribution of patients by baseline plasma HIV RNA and CD4 $4^{+}$T-lymphocyte category

\begin{tabular}{|c|c|c|c|c|c|}
\hline Marker & $N(\%)$ & $\begin{array}{l}\operatorname{AIDS}^{a} \\
N(\%)\end{array}$ & $\begin{array}{l}\text { Death }^{a} \\
N(\%)\end{array}$ & $\begin{array}{l}\text { Median time to } \\
\text { AIDS (y) }\end{array}$ & $\begin{array}{l}\text { Median time to } \\
\text { death }(y)\end{array}$ \\
\hline \multicolumn{6}{|c|}{ HIV RNA (copies/ml) } \\
\hline$<1000$ & $56(27.3)$ & $10(17.9)$ & $8(14.3)$ & 6.27 & 7.01 \\
\hline $1000-9999$ & $101(49.3)$ & $37(36.6)$ & $30(29.7)$ & 5.32 & 7.01 \\
\hline$\geq 10,000$ & $48(23.4)$ & $32(66.7)$ & $34(70.8)$ & 2.62 & 3.75 \\
\hline \multicolumn{6}{|c|}{$\mathrm{CD}^{+}{ }^{+} \mathrm{T}$ cells $\left(/ \mathrm{mm}^{3}\right)$} \\
\hline$\geq 500$ & $76(37.1)$ & $17(22.4$ & $9(11.8)$ & 6.53 & 7.01 \\
\hline $200-499$ & $71(34.6)$ & $19(26.8)$ & $17(23.9)$ & 5.03 & 6.85 \\
\hline$<200$ & $58(28.3)$ & $43(74.1)$ & $46(79.3)$ & 1.93 & 3.18 \\
\hline
\end{tabular}

${ }^{a}$ Participants were categorized as having AIDS if they met the 1987 U.S. Centers for Disease Control and Prevention surveillance definition within the first 7 years of follow-up, and all deaths occurring up to 7 years postenrollment were used in the analysis.

T lymphocytes were examined by comparing the log-transformed plasma HIV RNA concentrations and square root transformed $\mathrm{CD}^{+} \mathrm{T}$ lymphocytes between different genotype groups using two-sample unequal variance $t$-tests.

\section{RESULTS}

At the time of enrollment of the 207 seropositive individuals, mean age was 13.2 years, median $\mathrm{CD}^{+}{ }^{+} \mathrm{T}-$ lymphocyte count was $400 / \mathrm{mm}^{3}$, and the median plasma HIV RNA concentration was 3102 copies $/ \mathrm{ml}$, with 32 $(15.6 \%)$ having $<500$ copies/ml. Enrollment plasma HIV RNA and $\mathrm{CD}^{+} \mathrm{T}$ lymphocytes were significantly correlated with a Spearman rank correlation of $-0.46(p=$ $.0001)$. By 7 years of follow-up, 79 (38.5\%) had progressed to AIDS, and, in total, 72 AIDS-related deaths were reported. The median time from baseline to AIDS and death were 5.01 and 6.47 years, respectively. The distribution of total patients, as well as those who progressed to 1987 AIDS and AIDS-related death by plasma HIV RNA and $\mathrm{CD}^{+}$T-lymphocyte category are sum- marized in Table 1. Table 2 shows the unadjusted and adjusted relative hazard (RH) for progression to AIDS and AIDS-related death, showing that those with plasma HIV RNA concentrations $\geq 10,000$ copies $/ \mathrm{ml}^{\text {and }} \mathrm{CD} 4^{+}$ T lymphocytes $<200 / \mathrm{mm}^{3}$ were significantly different than the most favorable category in each group. Figure $1 A$ and $B$ show unadjusted data as Kaplan-Meier survival curves by plasma HIV RNA and $\mathrm{CD} 4^{+}$T-lymphocyte category, with Figure $2 A$ and $B$ showing unadjusted AIDS-free survival based on these markers.

Proportional hazards model was fitted with plasma HIV RNA concentrations and CD4 $4^{+} \mathrm{T}$-lymphocyte numbers treated as continuous variables, with and without adjustment for $\mathrm{CD}^{+}$T-lymphocyte or plasma HIV RNA category. For every threefold increase in plasma HIV RNA, there was an unadjusted RH of progression to AIDS and death of 1.79 and 1.86 , respectively. The adjusted RH for AIDS was 1.45 and death 1.41. Similarly, every 100-cell decrease in $\mathrm{CD}^{+} \mathrm{T}$ lymphocytes had an unadjusted RH for progression to AIDS and death of 2.97 and 4.62, respectively, with an adjusted RH for

TABLE 2. Unadjusted and adjusted relative hazard by baseline plasma HIV RNA and CD4 T-lymphocyte categories

\begin{tabular}{|c|c|c|c|c|}
\hline \multirow[b]{2}{*}{ Marker } & \multicolumn{2}{|c|}{ AIDS } & \multicolumn{2}{|c|}{ Death } \\
\hline & $\begin{array}{l}\text { Unadjusted RH } \\
\qquad(95 \% \mathrm{CI})\end{array}$ & $\begin{array}{l}\text { Adjusted } \mathrm{RH}^{a} \\
(95 \% \mathrm{CI})\end{array}$ & $\begin{array}{l}\text { Unadjusted RH } \\
\text { (95\% CI) }\end{array}$ & $\begin{array}{l}\text { Adjusted } \mathrm{RH}^{a} \\
(95 \% \mathrm{CI})\end{array}$ \\
\hline \multicolumn{5}{|c|}{ HIV RNA (copies/ml) } \\
\hline$<1000$ & 1.0 & 1.0 & 1.0 & 1.0 \\
\hline $1000-9999$ & $3.33^{b}(1.29-8.61)$ & $2.52(0.95-6.71)$ & $2.11(0.97-4.61)$ & $1.26(0.56-2.81)$ \\
\hline$\geq 10,000$ & $7.74^{c}(2.84-21.08)$ & $4.40^{c}(1.51-12.82)$ & $9.16^{c}(4.22-19.90)$ & $4.04^{c}(1.77-9.23)$ \\
\hline \multicolumn{5}{|c|}{$\mathrm{CD}^{+} \mathrm{T}$ cells $\left(/ \mathrm{mm}^{3}\right)$} \\
\hline$\geq 500$ & 1.0 & 1.0 & 1.0 & 1.0 \\
\hline $200-499$ & $1.57(0.77-3.18)$ & $1.22(0.59-2.53)$ & $2.26(1.01-5.08)$ & $1.78(0.77-4.10)$ \\
\hline$<200$ & $7.16^{c}(3.56-14.39)$ & $4.60^{c}(2.18-9.71)$ & $18.06^{c}(8.72-37.39)$ & $12.92^{c}(5.97-27.99)$ \\
\hline
\end{tabular}

${ }^{a}$ Relative hazard adjusted for $\mathrm{CD} 4^{+} \mathrm{T}$-lymphocytes or plasma HIV RNA categories.

${ }^{b} p<.05$.

${ }^{c} p<.01$.

$\mathrm{RH}$, relative hazard; CI, confidence intervals. 

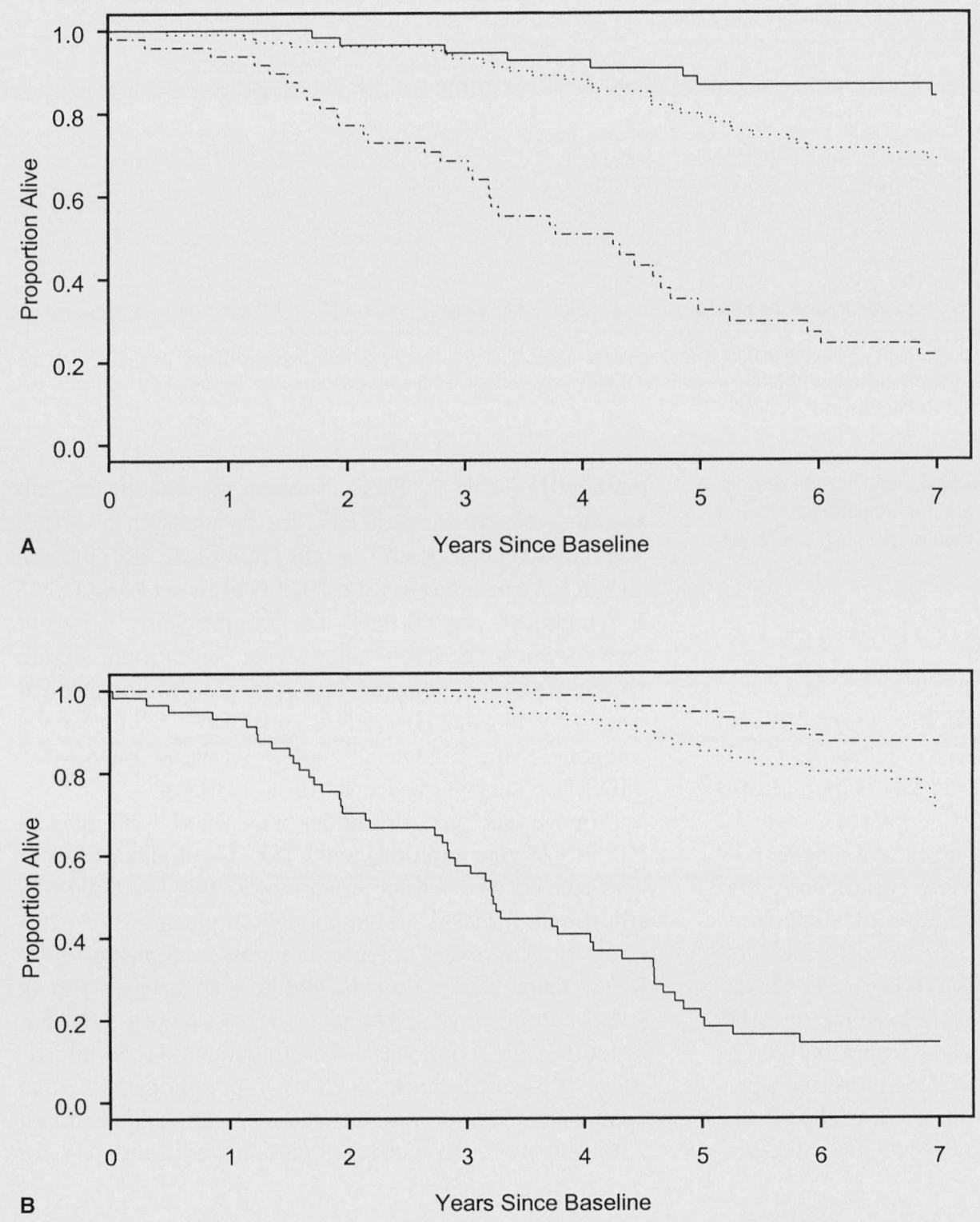

FIG. 1. Kaplan-Meier estimates for progression to AIDS-related death by baseline (A) plasma HIV RNA and (B) CD4 ${ }^{+}$T lymphocyte category. Solid line, $<1000$ copies/ $\mathrm{ml}$ and $<200$ cells $/ \mathrm{mm}^{3}$; dotted line, 1000-9999 copies/ml and 200499 cells $/ \mathrm{mm}^{3}$; dots-dashes line, $>10000$ copies $/ \mathrm{ml}$ and $>500$ cells $/$ $\mathrm{mm}^{3}$. Relative hazards and $p$ values are summarized in Table 2.
AIDS of 2.19 and 4.05 for death. All RH were statistically significant at $p<.01$.

$C C R 5$ and $C C R 2 b$ genotypes for the HGDS study subjects have been previously described as part of larger studies $(16,22)$. We characterized the study subjects in this cohort to determine the interactions between enrollment $\mathrm{CD}^{+}$T-lymphocyte number, plasma HIV RNA concentration, and chemokine receptor genotype. Table 3 summarizes the distribution of genotype variants for the cohort, and their relationship with enrollment plasma HIV RNA and CD4 ${ }^{+}$T-lymphocyte number. These analyses show that there are lower mean plasma HIV RNA and higher mean $\mathrm{CD}^{+}{ }^{+} \mathrm{T}$-lymphocyte numbers in all groups containing a $C C R 2 b$ or $C C R 5$ mutant allele. In fact, statistically higher mean $\mathrm{CD}^{+}$T-lymphocyte counts were found in all groups with the CCR $2 b-64 I$ allele $(p<.05)$, with nonsignificant differences observed in the $C C R 5-\triangle 32$ containing study subjects. Of the viral comparisons, there were trends toward lower plasma HIV RNA in the groups with the CCR2b-64I variant ( $p$ $=.07$ to .09 ) but not in those with the CCR5- $\Delta 32$ allele compared with wild-type $(p \geq .4)$. We further determined the interaction between chemokine receptor genotype, plasma HIV RNA concentration, $\mathrm{CD}^{+}{ }^{+} \mathrm{T}$ lymphocyte number, and disease progression. KaplanMeier survival curves comparing study subjects heterozygous for either chemokine receptor genotype variant to that wild-type for both for progression to AIDS 


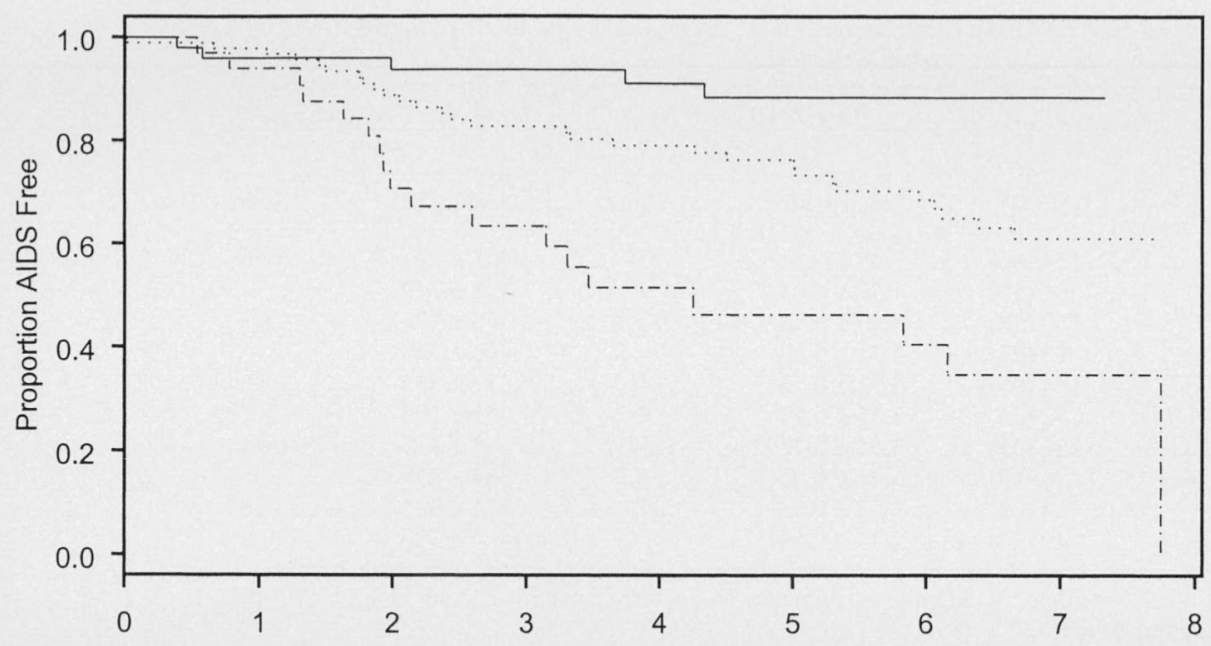

A

Years Since Baseline

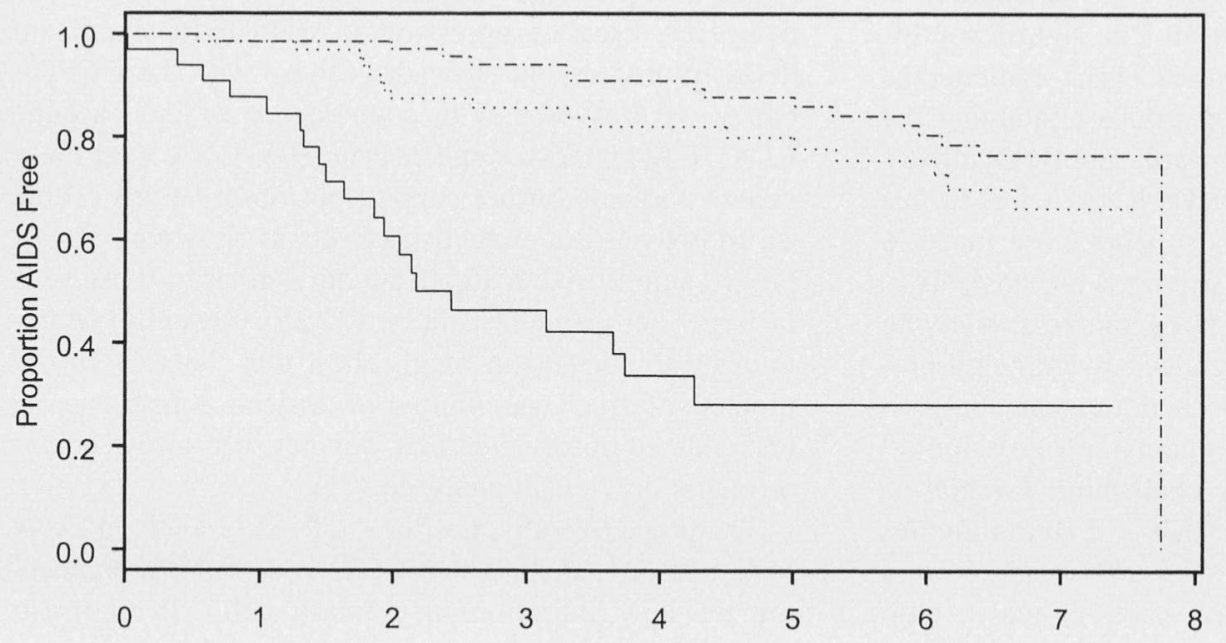

FIG. 2. Kaplan-Meier estimates for progression to the 1987 U.S. Centers for Disease Control and Prevention case definition of AIDS by baseline (A) plasma HIV RNA and (B) $\mathrm{CD}^{+} \mathrm{T}$ lymphocyte category. Solid line, $<1000$ copies/ml and $<200$ cells $/ \mathrm{mm}^{3}$; dotted line, 1000-9999 copies/ml and 200499 cells $/ \mathrm{mm}^{3}$; dots-dashes line, $>10000$ copies $/ \mathrm{ml}$ and $>500$ cells/ $\mathrm{mm}^{3}$. Relative hazards and $p$ values are summarized in Table 2.

B

Years Since Baseline

and AIDS-related death (Fig. 3). When the effect of each of these markers was assessed simultaneously, threefold increases in plasma HIV RNA were associated with a 1.41 to 1.45 times increased risk of progression to AIDS $(p \leq .004)$ and a 1.37 to 1.41 times increased risk of progression to AIDS-related death $(p \leq .008)$. Similarly, 100-cell decreases in $\mathrm{CD}^{+} \mathrm{T}$-lymphocyte number were associated with a 2.19 to 2.31 times increased risk of progression to AIDS $(p \leq .002)$ and 4.09 to 4.26 times increased risk of progression to death $(p<.001)$.

The Unadjusted and adjusted RH for HIV disease progression by chemokine receptor genotype is summarized in Table 4. These analyses show that although no statistically significant protection from progression to AIDS
( $p=.77)$ or death $(p=.55)$ is seen in those with the CCR5- $\Delta 32$ allele after adjusting for plasma HIV RNA and $\mathrm{CD}^{+}{ }^{+} \mathrm{T}$-lymphocyte number, there is a trend toward delayed progression to AIDS in those with the $C C R 2 b$ $64 I$ variant $(p=.092)$. A somewhat stronger relationship was seen for survival in the CCR2b-64I group compared with the wild-type $(p=.059)$ group and a significant protective effect for AIDS-related death seen in other comparisons between CCR2b-64I-containing groups $(p<.05)$.

\section{DISCUSSION}

This study shows that CD4 ${ }^{+}$T-lymphocyte number and plasma HIV RNA concentration predict HIV disease 
TABLE 3. Plasma HIV RNA concentration and $C D 4^{+} T$-lymphocyte number by chemokine receptor genotype

\begin{tabular}{|c|c|c|c|c|c|}
\hline \multirow[b]{2}{*}{ Genotype } & \multirow[b]{2}{*}{$\mathrm{N}(\%)$} & \multicolumn{2}{|c|}{$\begin{array}{c}\log ^{10}(\text { HIV RNA }) \\
(\text { copies/ml })\end{array}$} & \multicolumn{2}{|c|}{$\begin{array}{l}\mathrm{CD}^{+}{ }^{+} \mathrm{T} \text { lymphocytes } \\
\left(/ \mathrm{mm}^{3}\right)\end{array}$} \\
\hline & & Mean \pm SD & $p$ Value & Mean \pm SD & $p$ Value \\
\hline CCR $5+1+$ & $174(85)$ & $3.48 \pm 0.71$ & .404 & $405 \pm 321$ & .646 \\
\hline$C C R 5+/ \triangle 32$ & $31(15)$ & $3.37 \pm 0.64$ & & $403 \pm 239$ & \\
\hline$C C R 2 b+1+$ & $160(78)$ & $3.50 \pm 0.72$ & .070 & $380 \pm 304$ & .023 \\
\hline$C C R 2 b+164 I$ & $45(22)$ & $3.31 \pm 0.60$ & & $496 \pm 318$ & \\
\hline$C C R 5+/+, C C R 2 b+/+$ & $134(65)$ & $3.52 \pm 0.73$ & .071 & $379 \pm 315$ & .045 \\
\hline$C C R 5+1 \Delta 32, C C R 2 b+164 I$ & $71(35)$ & $3.35 \pm 0.61$ & & $455 \pm 295$ & \\
\hline$C C R 5+1+, C C R 2 b+1+$ & $134(65)$ & $3.52 \pm 0.72$ & .437 & $379 \pm 315$ & .614 \\
\hline$C C R 5+/ \triangle 32, C C R 2 b+/+$ & $26(13)$ & $3.41 \pm 0.63$ & & $384 \pm 239$ & \\
\hline$C C R 5+/+, C C R 2 b+/+$ & $134(65)$ & $3.52 \pm 0.73$ & .092 & $379 \pm 315$ & .038 \\
\hline$C C R 5+1+, C C R 2 b+164 I$ & $40(20)$ & $3.33 \pm 0.59$ & & $494 \pm 330$ & \\
\hline
\end{tabular}

$+/+$, homozygote for wild-type allele for chemokine receptors; $+/-$, heterozygote for mutant alleles $C C R 5-\Delta 32$ or $C C R 2 b-64 I$; SD, standard deviation.

progression in a cohort of infected children and adolescents (Table 2; Figs. 1 and 2). These analyses demonstrate that the CCR5 and $C C R 2 b$ chemokine receptor genotypes are related to plasma HIV RNA concentration and $\mathrm{CD} 4^{+} \mathrm{T}$-lymphocyte number. In fact, significant differences were observed between the $\mathrm{CD}^{+} \mathrm{T}$-lymphocyte number in all comparisons with groups containing the CCR $2 b-64 I$ allele and trends toward significant differences were seen in the plasma HIV RNA levels in this group (Table 3). These findings support those made in other cohorts. Furthermore, we extended our analysis to define the interaction between these markers, showing that the $C C R 2 b$ mutant allele trended toward being protective from progression to AIDS and, in some comparisons, significantly protective against progression to AIDS-related death, even after controlling for plasma HIV RNA concentration and $\mathrm{CD}^{+}{ }^{+} \mathrm{T}$ lymphocytes (Table 4).

The $C C R 5+/ \Delta 32$ genotype has been shown in individual studies and in a metaanalysis to postpone progression to AIDS $(16-19,21)$ and to be associated with lower plasma HIV RNA and higher $\mathrm{CD}^{+} \mathrm{T}$ lymphocytes (17, 19,36). Similarly, the presence of the CCR $2 b-64 I$ mutant allele has been shown to postpone progression to AIDS and death by 2 to 4 years in seroincident (22-25), but not in seroprevalent cohorts $(23,26-28,36)$. The lack of effect seen in previous studies using seroprevalent cohorts is likely to be a result of the exclusion of rapid progressors and imprecise estimation of the timing of seroconversion. Thus, it has been suggested that such cohorts not be used for studies to assess the protective effect of genetic variants. Such conclusions probably apply to seroprevalent cohorts of homosexual men, in whom the timing of infection varies. In contrast, hemophiliac cohorts are unique in that infection occurred during a relatively narrow window of time, between 1982 and 1983, allow- ing for a fairly precise estimation of the timing of seroconversion. Because of this, and despite the relatively small cohort and that rapid progressors are not included in our seroprevalent cohort, a trend toward protection from HIV disease progression to AIDS and a significant delay in progression to death in those with the $C C R 2 b$ $64 I$ allele was seen. The concordance of the baseline $\mathrm{CD} 4^{+} \mathrm{T}$ lymphocytes and plasma HIV RNA with these genetic variants further support our observations (Table 3). Moreover, the protective effects as shown by RH of progression to AIDS and death are similar to those seen in larger seroincident cohorts $(22,25)$. Recently, Mummidi et al. showed in their cohort that the CCR2b-64I protective effect was limited to African Americans, an unexplained observation that was not seen in our cohort or others previously analyzed (25).

The protective effect of the CCR5- $\Delta 32$ allele is likely to be related to the fact that $C C R 5$ is a principal coreceptor for HIV infection of primary cells. In contrast, $C C R 2 b$ is a minor coreceptor for HIV, and it is not clear why such a pronounced effect on disease progression would occur. Proposed mechanisms for protection include the role of this receptor in the transition of nonsyncytium-inducing to syncytium-inducing isolates (3740 ), the possible effect on the cellular expression of CCR5 $(41,42)$, or even indirect effects on HIV replication (38). In addition, Kostrikis et al. recently suggested that the effect could be related to a polymorphism identified in the CCR 5 promoter region of all study subjects with the $C C R 2 b-64 I$ allele (23). Although none of these mechanisms have been established in vivo, the protective effect of the CCR2b-64I allele is apparent. From a clinical perspective, it is most important to establish whether the presence of genotypic variants provide additional prognostic information to other established markers, such as plasma HIV RNA and CD4 ${ }^{+}$T-lymphocyte num- 


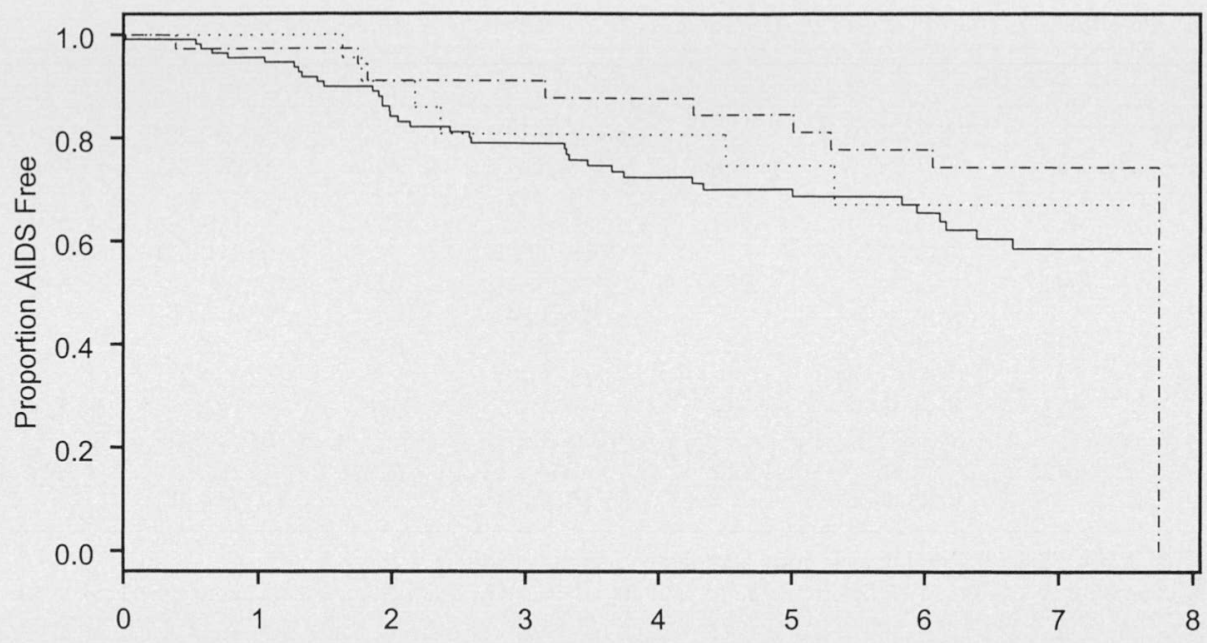

A

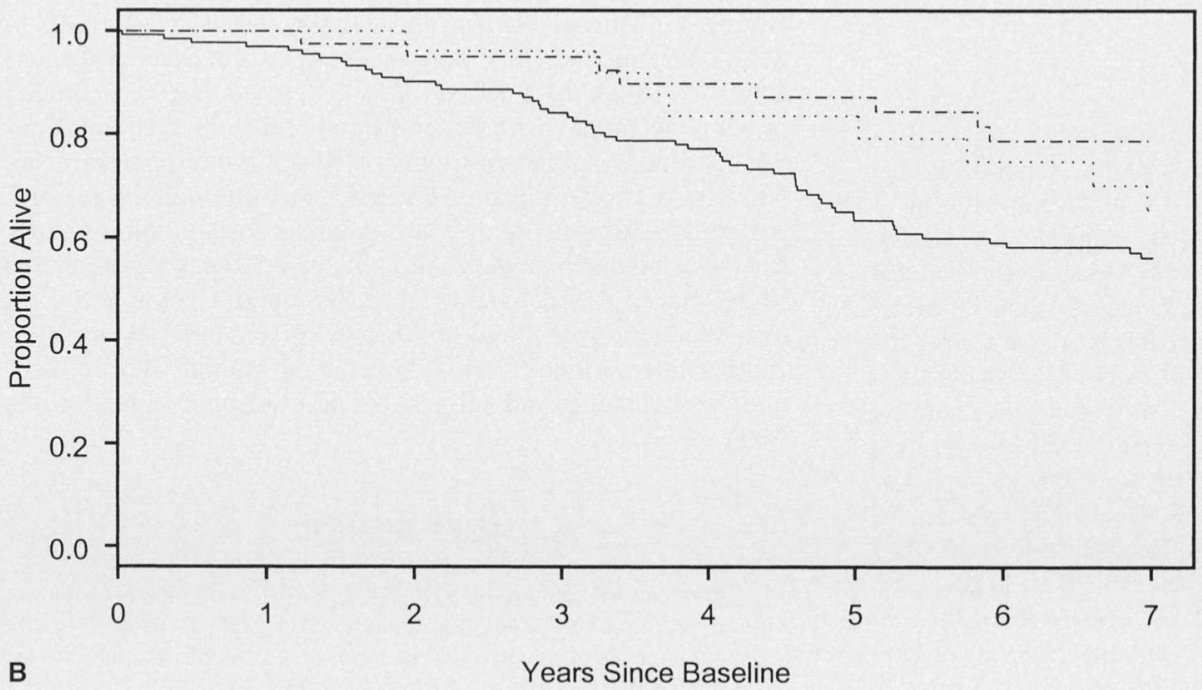

FIG. 3. Kaplan-Meier estimates of proportion of patients (A) AIDSfree and (B) surviving when comparing those with either the $C C R 2 b+/ 64$ I or $C C R 5+/ \Delta 32$ genotypes with those wild-type for both (CCR2b+l+ and CCR5+l+). Solid line, CCR $2 b+/+$ and $C C R 5+/+$; dotted line, CCR $2 b+l+$ and $C C R 5+$ $\Delta 32$; dots-dashes line, CCR2b+l 641 and $C C R 5+/+$. Relative hazard and $p$ values are summarized in Table 4. ber. Recent studies have described a relationship between the CCR2b-64I allele, CD4 ${ }^{+}$T-lymphocyte decline and plasma HIV RNA, suggesting that the beneficial effects of this genetic variant is mediated by its effect on these markers $(23,24)$. In the current study, we show a similar relationship between these markers. Moreover, we extended our analysis to show that the protective effect of the $C C R 2 b-64 I$ allele from progression to AIDS and particularly AIDS-related death appears to persist even after controlling for plasma HIV RNA and CD4 ${ }^{+}$ T-lymphocyte number. Together, these findings may provide new insight into the pathogenesis of HIV disease as well as establishing this genotypic variant as an independent predictor of disease progression.
Various interacting virologic and host factors determine the rate of disease progression in each HIVinfected individual. Although the $C C R 2 b$ and $C C R 5$ chemokine receptor variants have been shown to be protective, they do not explain all heterogeneity observed in the natural history of HIV infection. The inability to control for other known and unknown factors that influence progression to AIDS and death is likely to explain conflicting results across studies (43). Nevertheless, previously reported studies, which include multiple cohorts, have affirmed the significant effects of these chemokine receptor variants in the background of multiple confounders, such as race, HLA, age and undiscovered cofactors $(16,22)$. Further defining the mechanisms by which host 
TABLE 4. Unadjusted and adjusted relative hazards of AIDS and death by chemokine receptor genotype

\begin{tabular}{|c|c|c|c|c|c|c|c|c|}
\hline \multirow[b]{2}{*}{ Genotype } & \multicolumn{4}{|c|}{ AIDS } & \multicolumn{4}{|c|}{ Death } \\
\hline & $\begin{array}{l}\text { Unadjusted RH } \\
\qquad(95 \% \mathrm{CI})\end{array}$ & $p$ Value & $\begin{array}{l}\text { Adjusted } \mathrm{RH}^{a} \\
\quad(95 \% \mathrm{CI})\end{array}$ & $p$ Value & $\begin{array}{l}\text { Unadjusted RH } \\
(95 \% \mathrm{CI})\end{array}$ & $p$ Value & $\begin{array}{l}\text { Adjusted } \mathrm{RH}^{a} \\
(95 \% \mathrm{CI})\end{array}$ & $p$ Value \\
\hline $\begin{array}{l}\text { CCR5+/+ } \\
\text { CCR5+/ } 32\end{array}$ & $\begin{array}{c}1.42 \\
(0.61-3.34)\end{array}$ & .416 & $\begin{array}{c}1.14 \\
(0.48-2.70)\end{array}$ & .767 & $\begin{array}{c}1.34 \\
(0.66-2.69)\end{array}$ & .417 & $\begin{array}{c}1.24 \\
(0.61-2.53)\end{array}$ & .549 \\
\hline $\begin{array}{l}C C R 2 b+/+ \\
C C R 2 b+/ 64 I\end{array}$ & $\begin{array}{c}1.91 \\
(0.90-4.07)\end{array}$ & .094 & $\begin{array}{c}1.94 \\
(0.90-4.18)\end{array}$ & .092 & $\begin{array}{c}2.26 \\
(1.12-4.54)\end{array}$ & .022 & $\begin{array}{c}1.97 \\
(0.98-4.00)\end{array}$ & .059 \\
\hline $\begin{array}{l}C C R 5+/+, C C R 2 b+/+ \\
C C R 5+/ \Delta 32, C C R 2 b+164 I\end{array}$ & $\begin{array}{c}1.71 \\
(0.92-3.16)\end{array}$ & .089 & $\begin{array}{c}1.62 \\
(0.87-3.04)\end{array}$ & .131 & $\begin{array}{c}1.98 \\
(1.15-3.42)\end{array}$ & .014 & $\begin{array}{c}1.88 \\
(1.07-3.28)\end{array}$ & .027 \\
\hline $\begin{array}{l}C C R 5+/+, C C R 2 b+/+ \\
C C R 5+/ \Delta 32, C C R 2 b+/+\end{array}$ & $\begin{array}{c}1.33 \\
(0.56-3.14)\end{array}$ & .522 & $\begin{array}{c}1.16 \\
(0.49-2.77)\end{array}$ & .739 & $\begin{array}{c}1.51 \\
(0.72-3.17)\end{array}$ & .276 & $\begin{array}{c}1.60 \\
(0.75-3.41)\end{array}$ & .228 \\
\hline $\begin{array}{l}\text { CCR } 5+1+, C C R 2 b+/+ \\
\text { CCR } 5+/+, C C R 2 b+164 I\end{array}$ & $\begin{array}{c}1.78 \\
(0.83-3.82)\end{array}$ & .142 & $\begin{array}{c}1.86 \\
(0.85-4.06)\end{array}$ & .119 & $\begin{array}{c}2.44 \\
(1.16-5.13)\end{array}$ & .018 & $\begin{array}{c}2.35 \\
(1.11-4.99)\end{array}$ & .026 \\
\hline
\end{tabular}

${ }^{a}$ Relative hazards adjusted for plasma HIV RNA CD4 ${ }^{+} \mathrm{T}$ lymphocytes, and chemokine receptor genotype.

$+/+$, homozygote for wild-type allele for chemokine receptors; $+/-$, heterozygote for mutant alleles; RH, relative hazard; CI, confidence intervals.

factors delay HIV disease progression will not only advance our understanding of HIV immunopathogenesis, but it may also lead to novel therapeutic approaches in the future (44).

\section{APPENDIX}

The Hemophilia Growth and Development Study is funded by the following institutions: National Institutes of Health, National Institute of Child Health and Human Development-A. Willoughby; Bureau of Maternal and Child Health and Resources Development-W. Kessel; Centers for Disease Control and Prevention-Bruce Evatt; National Cancer Institute-S. O'Brien, C. Winkler; National Institute of Mental Health-W. Pequegnat. The following individuals are the Center Directors, Study Coordinators or Committee Chairs of the study: Childrens Hospital Los Angeles-E. Gomperts, W.Y. Wong, F. Kaufman, M. Nelson, S. Pearson; The New York Hospital-Cornell Medical Center-M. Hilgartner, S. Cunningham-Rundles, I. Goldberg; University of Texas Medical School, Houston-W. K. Hoots, K. Loveland, M. Cantini; The National Institutes of Health, National Institute of Child Health and Human Development-A. Willoughby; New England Research Institutes, Inc.-S. McKinlay, M. A. Maeder; Rho, Inc.-S. Donfield; Baylor College of Medicine - C. Contant; University of Iowa Hospitals and Clinics - C. T. Kisker, J. Stehbens, S. O'Conner, J. McKillip; Tulane University -P. Sirois; Children's Hospital of Oklahoma-C. Sexauer, H. Huszti, F. Kiplinger; S. Hawk; Mount Sinai Medical Center-S. Arkin, A. Forster; University of Nebraska Medical Center-S. Swindells, S. Richard; University of Texas Health Science Center, San Antonio-J. Mangos, A. Scott, R. Davis; Children's Hospital of Michigan-J. Lusher, I. Warrier, K. Baird-Cox; Milton S. Hershey Medical Center-M.E. Eyster, D. Ungar, S. Neagley; University of Indiana, James Whitcomb Riley Hospital for Children,-A. Shapiro J. Morris; University of California-San Diego Medical Center-G. Davignon, P. Mollen; Kansas City School of Medicine, Children's Mercy Hospital-B. Wicklund, A. Mehrhof.

Acknowledgments: The Hemophilia Growth and Development Study is supported by the Bureau of Maternal and Child Health and Resources Development (MCJ-060570), previously National Institute of Child Health and Human Development (NO1-HD-4-3200), the Centers for Disease Control and Prevention, the Laboratory of Genomic Diversity of the National
Cancer Institute, and the National Institute of Mental Health. Additional support has been provided by grants from the National Center for Research Resources of the National Institutes of Health to the New York Hospital-Cornell Medical Center Clinical Research Center (MO1-RR06020), the Mount Sinai General Clinical Research Center, New York (MO1RR00059), and the University of Texas Health Science Center, Houston, Texas (M)1-RR02558. This project has been funded in whole or in part with Federal Funds from the National Cancer Institute, National Institutes of Health, under Contract No. No. 11-Co-56000. Plasma HIV RNA measurements were supported by Chiron Corp. We are indebted to the children, adolescents, and parents who have volunteered to participate in this study; and to the members of the Hemophilia Treatment Centers. We are also indebted to Mary McNally of Science Applications International Corp., Frederick, National Cancer Institute, for managing and shipping of all clinical samples for this study.

\section{REFERENCES}

1. Tersmette M, Gruters RA, De Wolf F, et al. Evidence for a role of virulent human immunodeficiency virus (HIV) variants in the pathogenesis of acquired immunodeficiency syndrome; studies on sequential HIV isolates. J Virol 1989;63:2118-25.

2. Koot M, Keet IPM, Vos AHV, et al. Prognostic value of HIV-1 syncytium-inducing phenotype for rate of $\mathrm{CD} 4^{+}$cell depletion and progression to AIDS. Ann Intern Med 1993;118:681-8.

3. Daar ES, Chernyavskiy T, Zhao JQ, Krogstad P, Chen ISY, Zack JA. Sequential determination of viral load and phenotype in human immunodeficiency virus type 1 infection. AIDS Res Hum Retroviruses 1995;11:3-9.

4. Ho DD, Neumann AU, Perelson AS, Chen W, Leonard JM, Markowitz M. Rapid turnover of plasma virions and CD4 lymphocytes in HIV-1 infection. Nature 1995;373:123-6.

5. Wei X, Ghosh SK, Taylor ME, et al. Viral dynamics in human immunodeficiency virus type 1 infection. Nature 1995;373:11722.

6. Perelson AS, Neumann AU, Markowitz M, Leonard JM, Ho DD. HIV-1 dynamics in vivo: virion clearance rate, infected cell lifespan, and viral generation time. Science 1996;271:1582-6.

7. Mellors JW, Rinaldo CR, Jr, Gupta P, White RM, Todd JA, Kingsley LA. Prognosis in HIV-1 infection predicted by the quantity of virus in plasma. Science 1996;272:1167-70.

8. Mellors JW, Munoz A, Giorgi JV, et al. Plasma viral load and 
$\mathrm{CD} 4^{+}$lymphocytes as prognostic markers of HIV-1 infection. Ann Intern Med 1997;126:946-54.

9. Mofenson LM, Korelitz J, Meyer WA, III, et al. The relationship between serum human immunodeficiency virus type 1 (HIV-1) RNA level, CD4 lymphocyte percent, and long-term mortality risk in HIV-1-infected children. $J$ Infect Dis 1997;175:1029-38.

10. O'Brien TR, Blattner WA, Waters D, et al. Serum HIV-1 RNA levels and time to development of AIDS in the Multicenter Hemophilia Cohort Study. JAMA 1996;276:105-10.

11. Shearer WT, Quinn TC, LaRussa P, et al. Viral load and disease progression in infants infected with human immunodeficiency virus type 1. $N$ Engl J Med 1997;336:1337-42.

12. Vlahov D, Graham N, Hoover D, et al. Prognostic indicators for AIDS and infectious Disease death in HIV-infected injection drug users. JAMA 1998;279:35-40.

13. Darby SC, Ewart DW, Giangrande PLF, Spooner RJD, Rizza CR, Organisation for the UK Haemophilia Centre Director's. Importance of age at infection with HIV-1 for survival and development of AIDS in UK haemophilia population. Lancet 1996;347:1573-9.

14. Klein MR, Keet IP, D'Amaro J, et al. Associations between HLA frequencies and pathogenic features of human immunodeficiency virus type 1 infection in seroconverters from the Amsterdam cohort of homosexual men. J Infect Dis 1994;169:1244-9.

15. Kaslow R, Carrington M, Apple R, et al. Influence of combinations of major histocompatibility complex genes on the course of HIV-1 infection. Nat Med 1996;2:405-11.

16. Dean $\mathrm{M}$, Carrington $\mathrm{M}$, Winkler $\mathrm{C}$, et al. Genetic restriction of HIV-1 infection and progression to AIDS by a deletion allele of the CKR5 structural gene. Science 1996;273:1856-62.

17. Huang Y, Paxton WA, Wolinsky SM, et al. The role of a mutant CCR5 allele in HIV-1 transmission and disease progression. Nat Med 1996;11:1240-3.

18. Michael NL, Chang G, Louie LG, et al. The role of viral phenotype and ccr- 5 gene defects in HIV-1 transmission and disease progression. Nat Med 1997;3:338-40.

19. de Roda Husman A-M, Koot M, Cornelissen M, et al. Association between CCR5 genotype and the clinical course of HIV-1 infection. Ann Intern Med 1997;127:882-90.

20. Eugen-Olsen J, Iversen AKN, Garred P, et al. Heterozygosity for a deletion in the CKR-5 gene leads to prolonged AIDS-free survival and slower CD4 T-cell decline in a cohort of HIVseropositive individuals. AIDS 1997;11:305-10.

21. Misrahi M, Tegias J-P, N'Go N, et al. CCR5 chemokine receptor variant in HIV-1 mother-to-child transmission and disease progression in children. JAMA 1998;279:277-80.

22. Smith MW, Dean M, Carrington M, et al. Contrasting genetic influence of CCR2 and CCR5 variants on HIV-1 infection and disease progression. Science 1997;277:959-65.

23. Kostrikis LG, Huang Y, Moore JP, et al. A chemokine receptor CCR2 allele delays HIV-1 disease progression and is associated with a CCR5 promoter mutation. Nat Med 1998;4:350-3.

24. Rizzardi GP, Morawetz RA, Vicenzi E, et al. CCR2 polymorphism and HIV disease. Nat Med 1998;4:252-3.

25. Mummidi S, Ahuja SS, Gonzalez E, et al. Genealogy of the CCR5 locus and chemokine system gene variants associated with altered rates of HIV-1 disease progression. Nat Med 1998;4:786-93.
26. Michael NL, Louie LG, Rohrbaugh AL, et al. The role of CCR5 and CCR2 polymorphisms in HIV-1 transmission and disease progression. Nat Med 1997;3:1160-2.

27. Smith MW, Carrington M, Winkler C, et al. CCR2 chemokine receptor and AIDS progression. Nat Med 1997;3:1052-3.

28. Eugen-Olsen J, Iversen AKN, Benfield TL, Koppelhus U, Garred $\mathrm{P}$, Cohort for the Copenhagen AIDS. Chemokine receptor CCR2b 64I polymorphism and its relation to CD4 T-cell counts and disease progression in a Danish Cohort of HIV-infected individuals. $J$ Acquir Immune Defic Syndr Hum Retrovirol 1998;18:110-6.

29. CDC. Hemophilia surveillance system report. MMWR Morb Mortal Wkly Rep 1998;1:1-14.

30. Hilgartner MW, Donfield SM, Willoughby A, et al. Hemophilia Growth and Development Study. Am J Pediatr Hematol Oncol 1993;15:208-18.

31. CDC. Revision of the CDC surveillance case definition for acquired immune deficiency. MMWR Morb Mortal Wkly Rep 1987; 36:1S-15S.

32. Dewar RL, Highbarger HC, Sarmiento MD, et al. Application of branched DNA signal amplification to monitor human immunodeficiency virus type 1 burden in human plasma. J Infect Dis 1994; 170:1172-9.

33. Todd J, Pachl C, White R, et al. Performance characteristics for the quantitation of plasma HIV-1 RNA using branched DNA signal amplification technology. J Acquir Immune Defic Syndr Hum Retrovirol 1995;10(Suppl 2):S35-S44.

34. Hand DJ. Discrimination and classification. New York: John Wiley \& Sons, 1981.

35. Grambsch PM, Therneau TM. Proportional hazards tests and diagnostics based on weighted residuals. Biometrika 1994;81:51526.

36. Ioannidis JPA, O'Brien TR, Rosenberg PS, Contopoulos-Ioannidis DG, Goedert JJ. Genetic effects on HIV disease progression. Nat Med 1998;4:536.

37. Doranz BJ, Rucker J, Yi Y, et al. A dual-tropic primary HIV-1 isolate that uses fusin and the beta-chemokine receptors CKR-5, CKR-3, and CKR-2b as fusion cofactors. Cell 1996;85:1149-58.

38. Frade JMR, Liorente M, Mellado M, et al. The amino-terminal domain of the CCR2 chemokine receptor acts as coreceptor for HIV-1 infection. J Clin Invest 1997;100:497-502.

39. Rucker J, Samson M, Doranz BJ, et al. Regions in beta-chemokine receptors CCR5 and CCR2b that determine HIV-1 cofactor specificity. Cell 1996;87:437-46.

40. Arenzapa-Sciadepos F, Virelizier J-L, Rousset D, et al. HIV blocked by chemokine antagonist. Nature 1996;383:400.

41. Bleul CC, Wu L, Hoxie JA, Springer TA, Mackay CR. The HIV coreceptors CXCR4 and CCR5 are differentially expressed and regulated on human T lymphocytes. Proc Natl Acad Sci USA 1997; 94:1925-30.

42. Wu L, Paxton WA, Kassam N, et al. CCR5 levels and expression pattern correlate with infectability by macrophage-tropic HIV-1, in vitro. J Exp Med 1997;185:1681-91.

43. Collman RG. Effect of CCR2 and CCR5 variants on HIV disease. JAMA 1997:278:2113-4

44. Cairns JS, D'Souza MP. Chemokines and HIV-1 second receptors: the therapeutic connection. Nat Med 1998;4:563-8. 